\title{
INFLUENCE OF CHITOSAN AND MICRONUTRIENTS (FE + ZN) CONCENTRATIONS ON GROWTH, YIELD COMPONENTS AND VOLATILE OIL OF LAVENDER PLANT
}

\author{
Asmaa A. Fahmy and W.S. Nosir \\ Horticulture Department, Faculty of Agriculture, Zagazig University, Egypt
}

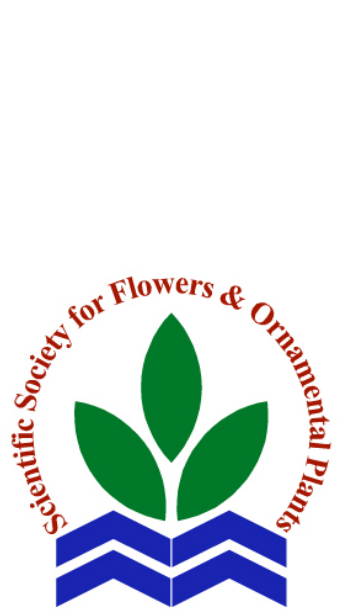

ABSTRACT: To study the influence of the two factors of chitosan
concentration $(0.0,100,200$ and $400 \mathrm{ppm})$, micronutrients as $\mathrm{FeSO}_{4}+$
$\mathrm{ZnSO}_{4}(0.0,50,100$ and $200 \mathrm{ppm})$ and their combination treatments on
plant growth, yield components, volatile oil production, total
carbohydrates \% and total chlorophyll content (SPAD unit), two filed
experiments were conducted on lavender (Lavandula officinalis,
Chaix.) during the two summer consecutive seasons of 2018 and 2019
at Agric. Res. Farm, Fac. Agric., Zagazig Univ., Egypt. The
Experimental layout was split-plot design between the four chitosan
concentrations as main plots and the four micronutrients concentration
as sub-plots in randomized complete blocks design with 3 replicates.
The obtained results referred to that using chitosan concentration of
400 ppm significantly increased growth parameters (plant height,

Scientific J. Flowers \& number of branches/plant, fresh and dry weights of roots/plant as well Ornamental Plants, as root number and length), yield components (total dry herb 8(1):87-100 (2021). yield/plant and /feddan), volatile oil production (volatile oil percentage

Received:

$6 / 12 / 2020$

Accepted:

20/12/2020

Corresponding author: Asmaa A. Fahmy galal_dr@yahoo.com and volatile oil yield per plant) and chemical constituents (total chlorophyll content and total carbohydrates percentage) compared to control and the other levels under study. Furthermore, the highest values in these characters were noticed by micronutrients at $200 \mathrm{ppm}$ treatment in both seasons, in most cases. In general, it is preferable to spray lavender plants with chitosan at $400 \mathrm{ppm}$ combined with $\mathrm{Fe}+\mathrm{Zn}$ at $200 \mathrm{ppm}$ five times a season to increase the plant growth, yield components and plant pigments as well as volatile oil production of this important aromatic plant.

Key words: Lavender, chitosan, Fe, Zn, growth, root, yield, volatile oil, total chlorophyll.

\section{INTRODUCTION}

Lavender (Lavandula officinalis, Chaix), belongs to family Labiatae (Hassanpouraghdam et al., 2011). However, lavender is utilized as ornamental plant in private and public gardens in order to its beautiful foliage and flowers (Lawless, 1995). It is preferable recognized for its flowers which contain essential oil which is utilized medicinally, in perfumes, salves, balms, cosmetics. Lavender essential oil has analgesic, antifungal, anti-inflammatory, antiseptic and bactericidal properties for it is load terpenes [Worwood, 1991; Schnaubelt, 1998 and Yusufoglu et al., 2004]. Lavender is extremely utilized as relaxation and an aid to sleep. Extract of lavender is claimed to heal acne, it is also utilized in therapy of inflammatory and skin burns conditions.

Chitosan is considered as a low toxic, biodegradable and assess efficient substance created by deacetylation process of chitin (Iriti et al., 2009), utilized in several agricultural production and medicine 
industries (Pichyangkura and Chadchawan, 2015). Moreover, chitosan may act as an exogenous elicitor to enhance plant protection (Pirbalouti et al., 2017). Different planning has been investigated to find the eco-friendly solutions for enhancing crop growth and productivity among which chitosan is a suitable candidate, taking into account sustainable agriculture (Malerba and Cerana, 2018 and Maluin and Hussein,2020).

Iron $(\mathrm{Fe})$ and zinc $(\mathrm{Zn})$ as micronutrients ordinarily added as foliar fertilizers so as to compensate their shortage essentially in arid and semi-arid regions (Kaya et al., 2005). Micronutrients, especially iron and Zinc, act either as mineral ingredient of several enzymes or as regulatory cofactors, functional and structural. Consequently, they are correlating with protein synthesis, saccharides metabolism or photosynthesis (Marschner, 1995). In addition, Soliman et al. (2018) found that micronutrients of $\mathrm{Fe}+$ $\mathrm{Zn}+\mathrm{Mo}$ at $0.50+0.30+3 \mathrm{~g} / \mathrm{l}$, respectively as foliar spray increased growth, yield components and active ingredients of Stevia rebaudiana compared to control (sprayed with tap water).

The current study was executed with the target of evaluating the influences of foliar application of chitosan and $\mathrm{Fe}+\mathrm{Zn}$ as well as their interactions on the growth and productivity of lavender plants and illustrating the involved mechanisms in this important plant.

\section{MATERIALS AND METHODS}

This study was conducted during the two consecutive summer seasons of 2018 and 2019 at the Agric. Res. Farm, Fac. Agric.,
Zagazig Univ., Egypt. This work was carried out to examine the influence of chitosan concentrations $(0.0,100,200$ and $400 \mathrm{ppm})$, micronutrients concentrations [control (sprayed with tap water), 50, 100 and 200 $\mathrm{ppm}$ of $\left.\left(\mathrm{FeSO}_{4}+\mathrm{ZnSO}_{4}\right)\right]$ as foliar applications and their interaction treatments on lavender growth, yield, volatile oil, total carbohydrates percentage and total chlorophyll content. Table (1) showed some physical and chemical analysis of the experimental soil at a depth of $0-30 \mathrm{~cm}$ according to Chapman and Pratt (1978). The current experiment was set up in a split-plot design with 3 replicates. The main plots were occupied by four chitosan concentrations. The sub plots were entitled to four micronutrients concentrations. The combination treatments between main plot and sub plot were 16 treatments.

However, lavender plants were sprayed with chitosan and micronutrients concentrations five times at 30, 45, 60, 75 and 90 days after planting date. The source of chitosan $\left(\mathrm{C}_{56} \mathrm{H}_{103} \mathrm{~N}_{9} \mathrm{O}_{39}\right)$ was Modern Agricide Company (New Cairo, Cairo, Egypt) as solution (96.40\%) as well as the source of $\mathrm{FeSO}_{4}$ and $\mathrm{ZnSO}_{4}$ was ElGomhoria Chemical Company, Egypt.

The plot area was $14.40 \mathrm{~m}^{2}(4.00 \times 3.60$ $\mathrm{m})$ included six ridges. Each ridge was 60 $\mathrm{cm}$ wide and four meters length. The distance between lavender plants in the ridge was $40 \mathrm{~cm}$, under surface irrigation system. Private nursery in Belbas District, Sharkia Governorate, Egypt was the source of lavender seedlings. All seedlings were similar in growth and $10 \mathrm{~cm}$ in length. Seedlings were planted in the experimental

Table 1. Some physical and chemical analyses of the experimental soil (average of the two seasons).

\begin{tabular}{|c|c|c|c|c|c|c|c|c|c|c|c|c|}
\hline & \multicolumn{9}{|c|}{ Physical analysis } & \multicolumn{3}{|c|}{ Soil texture } \\
\hline & Clay (\%) & \multicolumn{2}{|c|}{ Silt (\%) } & \multicolumn{3}{|c|}{ Fine sand (\%) } & \multicolumn{3}{|c|}{ Coarse sand (\%) } & \multirow{2}{*}{\multicolumn{3}{|c|}{ Clayey }} \\
\hline & 41.33 & \multicolumn{2}{|c|}{19.24} & \multicolumn{3}{|c|}{15.68} & \multicolumn{3}{|c|}{23.75} & & & \\
\hline \multicolumn{13}{|c|}{ Chemical analysis } \\
\hline \multirow[t]{2}{*}{ pH } & \multirow{2}{*}{$\begin{array}{c}\text { EC } \\
\text { mmohs/cm }\end{array}$} & \multirow{2}{*}{$\begin{array}{c}\text { Organic } \\
\text { mater }(\%)\end{array}$} & \multicolumn{4}{|c|}{$\begin{array}{c}\text { Soluble cations } \\
(\mathrm{meq} / \mathrm{l})\end{array}$} & \multicolumn{3}{|c|}{$\begin{array}{l}\text { Soluble anions } \\
\quad(\mathrm{meq} / \mathrm{l})\end{array}$} & \multicolumn{3}{|c|}{$\begin{array}{l}\text { Available } \\
\text { (ppm) }\end{array}$} \\
\hline & & & $\mathbf{M g}^{++}$ & $\mathrm{Ca}^{++}$ & $\mathbf{K}^{+}$ & $\mathrm{Na}^{+}$ & $\mathrm{Cl}^{-}$ & $\mathrm{HCO}_{3}^{-}$ & $\mathrm{SO}_{4}^{--}$ & $\mathbf{N}$ & $\mathbf{P}$ & $\mathbf{K}$ \\
\hline 7.79 & 0.99 & 0.61 & 2.8 & 1.7 & 1.6 & 3.8 & 4.5 & 1.8 & 3.6 & 28 & 11 & 82 \\
\hline
\end{tabular}


plots on $8^{\text {th }}$ April and $12^{\text {th }}$ April during the 2018 and 2019 seasons, respectively.

All the recommended agricultural practices of planted lavender were done when ever needed. All treatments were fertilized with single calcium superphosphate $\left(15.5 \% \mathrm{P}_{2} \mathrm{O}_{5}\right)$ at $200 \mathrm{~kg}$, potassium sulphate $\left(48 \% \mathrm{~K}_{2} \mathrm{O}\right)$ at $100 \mathrm{~kg}$ and ammonium nitrate $(33 \% \mathrm{~N})$ at $150 \mathrm{~kg}$ per feddan. Phosphorus and potassium fertilizers were applied during soil preparation, while, nitrogen fertilizer was divided into three equal doses and were added to the soil at 35, 60 and 85 days after planting date.

\section{Data recorded:}

After 155 days from transplanting, three lavender plants were randomly chosen from each plot to determine the following parameters:

1. Plant growth: plant height $(\mathrm{cm})$, number of branches/plant, fresh and dry weights of roots/plant $(\mathrm{g})$, root number/plant and root length $(\mathrm{cm})$ for the longest root were recorded.

2. Dry herb yield: dry herb yield per plant ( $\mathrm{g}$ ) and per faddan $(\mathrm{kg})$ were calculated.

3. Volatile oil production: the volatile oil from lavender leaves air-dried was isolated by hydro distillated for $3 \mathrm{hr}$. to extract the volatile oil as described by Guenther (1961) and the volatile oil yield per plant $(\mathrm{ml})$ was calculated.

4. Chemical constituents: at harvest time, total chlorophyll content (SPAD unit) was determined in lavender fresh leaves by utilizing SPAD-502 meter (Markwell et al., 1995). Also, total carbohydrate percentage in lavender leaves was determined according to the method reported by Dubois et al. (1956).

\section{Statistical Analysis:}

Collected data were analyzed as presented by Gomez and Gomez (1984). Least significance difference (L.S.D.) was utilized to differentiate means at the at 5\% level of probability. The means were compared utilizing computer program of Statistix version 9 (Analytical software, 2008).

\section{RESULTS AND DISCUSSION}

\section{Plant growth parameters:}

Data of both seasons presented in Tables (2, 3 and 4) show that plant height $(\mathrm{cm})$, branch number per plant, roots fresh and dry weights per plant (g) as well as root number per plant and root length $(\mathrm{cm})$ of lavender (Lavandula officinalis, Chaix) were increased by using chitosan concentrations compared to control during both seasons. This increase was significant in the first and second seasons. Mostly, the highest values in this concern were achieved by $400 \mathrm{ppm}$ concentration compared to the other ones under study. Similar positive influences of chitosan application were noticed in basil cultivation, in which a significant plant development and growth (Malekpoor et al., 2016) as well as in case of Stevia rebaudiana where chitosan influenced significantly on dry and fresh weights of stem, leaves and roots per plant (Mehregan et al., 2017).

The results tabulated in Tables 2, 3 and 4 indicate that lavender plants sprayed five times/season with $\mathrm{Fe}+\mathrm{Zn}$ at any concentration recorded the highest values of plant height, number of branches per plant, root fresh and dry weights per plant, root number per plant and root length with significant differences between chitosan concentrations and control in both seasons. Meantime, the best treatment for increasing lavender growth parameters was that 400 ppm compared to the other foliar concentrations in the two tested seasons. Similar results were demonstrated by Zehtab-Salmasi et al. (2008) on peppermint, Ziedan and Eisa (2016) on dill and Mehrab (2017) on lemon balm plants.

The influence of chitosan interacted with micronutrients concentrations on lavender growth parameters during 2018 and 2019 seasons were tabulated in Tables 2, 3 and 4. Since, the highest values in this concern were obtained by the interaction treatment of 
Table 2. Influence of chitosan (C) and micronutrients concentration (M) as well as their interaction $(\mathrm{C} \times \mathrm{M})$ treatments on plant height and number of branches/plant of lavender plant during the two seasons of 2018 and 2019.

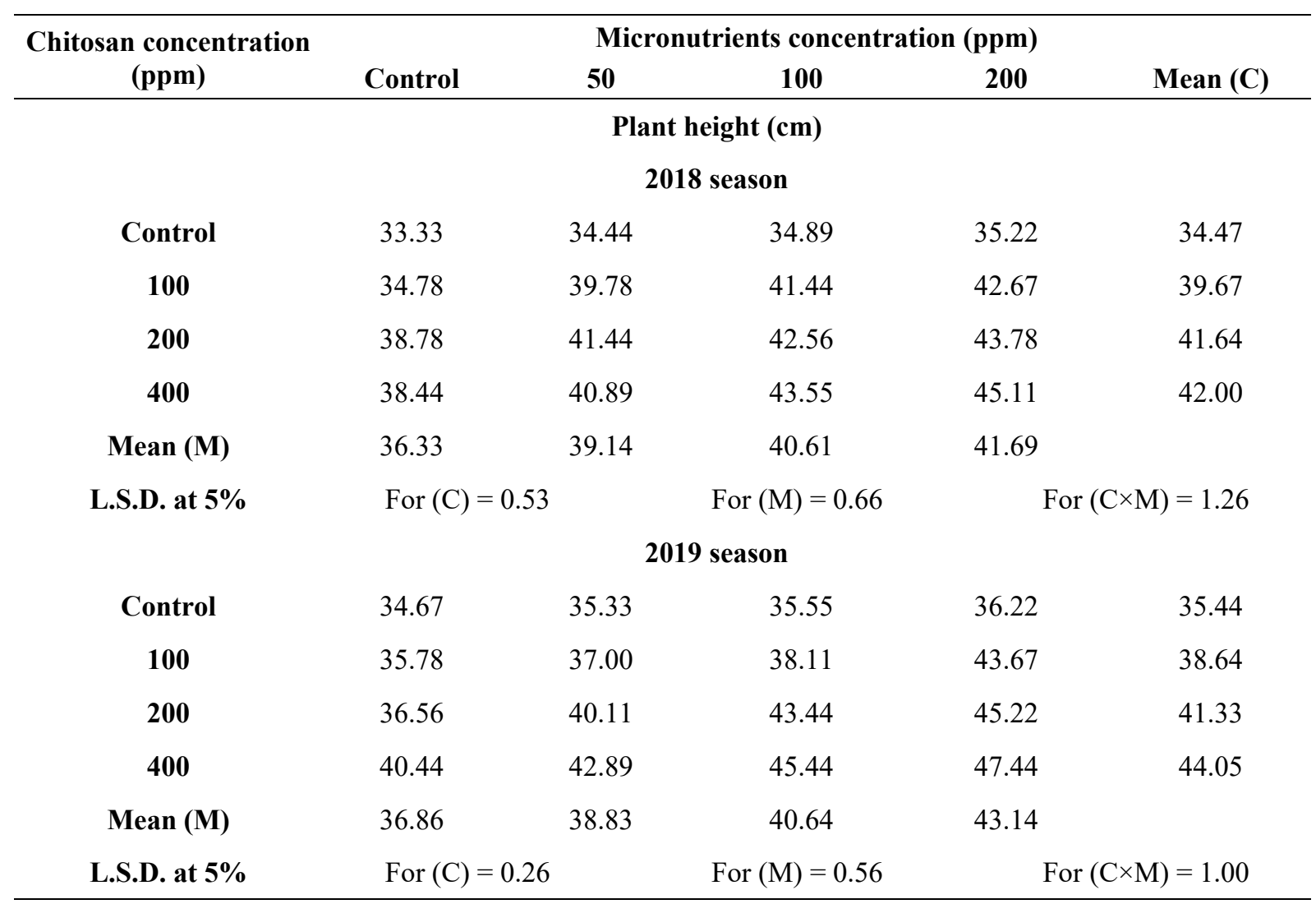

Number of branches/plant

2018 season

$\begin{array}{cccccc}\text { Control } & 23.22 & 23.78 & 25.11 & 25.34 & 24.36 \\ \mathbf{1 0 0} & 23.22 & 24.67 & 26.66 & 27.56 & 25.53 \\ \mathbf{2 0 0} & 24.89 & 26.55 & 28.00 & 30.11 & 27.39 \\ \mathbf{4 0 0} & 26.89 & 27.33 & 28.45 & 31.78 & 28.61 \\ \text { Mean (M) } & 24.56 & 25.58 & 27.06 & 28.70 & \end{array}$

$\begin{array}{llll}\text { L.S.D. at 5\% } & \text { For }(\mathrm{C})=0.33 & \text { For }(\mathrm{M})=0.40 & \text { For }(\mathrm{C} \times \mathrm{M})=0.77\end{array}$

2019 season

$\begin{array}{cccccc}\text { Control } & 21.44 & 23.56 & 23.89 & 26.33 & 23.81 \\ \mathbf{1 0 0} & 22.00 & 23.22 & 25.78 & 27.00 & 24.50 \\ \mathbf{2 0 0} & 23.78 & 24.89 & 27.44 & 28.89 & 26.25 \\ \mathbf{4 0 0} & 26.00 & 28.55 & 30.56 & 33.00 & 29.53 \\ \text { Mean (M) } & 23.31 & 25.05 & 26.92 & 28.81 & \end{array}$

L.S.D. at $5 \%$

For $(C)=0.70$

For $(\mathrm{M})=0.50$

For $(\mathrm{C} \times \mathrm{M})=1.11$ 
Table 3. Influence of chitosan (C) and micronutrients concentrations (M) as well as their interaction $(\mathrm{C} \times \mathrm{M})$ treatments on fresh and dry weights of roots/plant $(\mathrm{g})$ of lavender plant during the two seasons of 2018 and 2019.

\begin{tabular}{|c|c|c|c|c|c|}
\hline \multirow{2}{*}{$\begin{array}{c}\text { Chitosan concentration } \\
(\mathrm{ppm})\end{array}$} & \multicolumn{4}{|c|}{ Micronutrients concentration (ppm) } & \multirow{2}{*}{ Mean (C) } \\
\hline & Control & 50 & 100 & 200 & \\
\hline \multicolumn{6}{|c|}{ Fresh weight of roots/plant (g) } \\
\hline \multicolumn{6}{|c|}{2018 season } \\
\hline Control & 18.79 & 19.34 & 20.29 & 20.72 & 19.78 \\
\hline 100 & 19.29 & 20.26 & 21.01 & 22.00 & 20.64 \\
\hline 200 & 20.35 & 22.29 & 24.09 & 27.00 & 23.43 \\
\hline 400 & 20.90 & 23.40 & 24.42 & 27.15 & 23.97 \\
\hline Mean (M) & 19.83 & 21.32 & 22.45 & 24.22 & \\
\hline L.S.D. at 5\% & \multicolumn{2}{|c|}{ For $(C)=0.40$} & \multicolumn{2}{|c|}{ For $(M)=0.36$} & For $(C \times M)=0.73$ \\
\hline \multicolumn{6}{|c|}{2019 season } \\
\hline Control & 18.92 & 19.78 & 20.83 & 21.35 & 20.22 \\
\hline 100 & 19.58 & 21.22 & 21.92 & 23.12 & 21.46 \\
\hline 200 & 19.78 & 21.74 & 23.29 & 25.93 & 22.68 \\
\hline 400 & 20.27 & 22.32 & 23.99 & 26.21 & 23.20 \\
\hline Mean (M) & 19.64 & 21.26 & 22.51 & 24.15 & \\
\hline L.S.D. at 5\% & \multicolumn{2}{|c|}{ For $(C)=0.37$} & For $(M)=0$ & \multicolumn{2}{|c|}{ For $(C \times M)=0.82$} \\
\hline \multicolumn{6}{|c|}{ Dry weight of roots/plant (g) } \\
\hline \multicolumn{6}{|c|}{2018 season } \\
\hline Control & 8.36 & 8.70 & 9.18 & 9.07 & 8.83 \\
\hline 100 & 8.72 & 8.93 & 9.09 & 9.18 & 8.98 \\
\hline 200 & 9.23 & 9.98 & 11.00 & 11.25 & 10.37 \\
\hline 400 & 9.24 & 9.68 & 11.02 & 11.70 & 10.41 \\
\hline Mean (M) & 8.89 & 9.32 & 10.07 & 10.30 & \\
\hline L.S.D. at 5\% & \multicolumn{2}{|c|}{ For $(C)=0.25$} & For $(\mathrm{M})=0.1$ & \multicolumn{2}{|c|}{ For $(C \times M)=0.35$} \\
\hline \multicolumn{6}{|c|}{2019 season } \\
\hline Control & 8.45 & 8.94 & 9.13 & 9.28 & 8.95 \\
\hline 100 & 8.93 & 9.19 & 9.54 & 9.75 & 9.35 \\
\hline 200 & 8.98 & 9.84 & 10.82 & 11.07 & 10.18 \\
\hline 400 & 9.37 & 10.11 & 11.12 & 11.16 & 10.44 \\
\hline Mean (M) & 8.93 & 9.52 & 10.15 & 10.32 & \\
\hline L.S.D. at 5\% & \multicolumn{2}{|c|}{ For $(C)=0.28$} & For $(M)=0$. & \multicolumn{2}{|c|}{ For $(C \times M)=0.37$} \\
\hline
\end{tabular}


Table 4. Influence of chitosan (C) and micronutrients concentrations (M) as well as their interaction $(\mathrm{C} \times \mathrm{M})$ treatments on root number/plant and root length $(\mathrm{cm})$ of lavender plant during the two seasons of 2018 and 2019.

\begin{tabular}{|c|c|c|c|c|c|}
\hline \multirow{2}{*}{$\begin{array}{c}\text { Chitosan concentration } \\
(\mathbf{p p m})\end{array}$} & \multicolumn{4}{|c|}{ Micronutrients concentration (ppm) } & \multirow{2}{*}{ Mean $(\mathrm{C})$} \\
\hline & Control & 50 & 100 & 200 & \\
\hline \multicolumn{6}{|c|}{ Root number/plant } \\
\hline \multicolumn{6}{|c|}{2018 season } \\
\hline Control & 17.11 & 18.11 & 18.11 & 18.44 & 17.94 \\
\hline 100 & 18.55 & 20.33 & 22.11 & 23.55 & 21.14 \\
\hline 200 & 18.55 & 20.33 & 22.11 & 23.55 & 21.14 \\
\hline 400 & 19.56 & 21.11 & 23.00 & 24.22 & 21.97 \\
\hline Mean (M) & 18.44 & 19.97 & 21.33 & 22.44 & \\
\hline L.S.D. at $5 \%$ & \multicolumn{2}{|c|}{ For $(C)=0.32$} & \multicolumn{2}{|l|}{ For $(\mathrm{M})=0.38$} & For $(\mathrm{C} \times \mathrm{M})=0.73$ \\
\hline \multicolumn{6}{|c|}{2019 season } \\
\hline Control & 17.78 & 18.33 & 18.78 & 19.00 & 18.47 \\
\hline 100 & 18.67 & 19.11 & 20.11 & 21.44 & 19.83 \\
\hline 200 & 20.11 & 19.11 & 19.89 & 21.44 & 20.14 \\
\hline 400 & 20.78 & 21.22 & 22.11 & 23.78 & 21.97 \\
\hline Mean (M) & 19.33 & 19.44 & 20.22 & 21.42 & \\
\hline L.S.D. at 5\% & \multicolumn{2}{|c|}{ For $(C)=0.55$} & For $(M)=0.60$ & \multicolumn{2}{|c|}{ For $(C \times M)=1.18$} \\
\hline \multicolumn{6}{|c|}{ Root length (cm) } \\
\hline \multicolumn{6}{|c|}{2018 season } \\
\hline Control & 16.44 & 17.22 & 17.78 & 18.89 & 17.58 \\
\hline 100 & 18.11 & 18.44 & 19.34 & 20.67 & 19.13 \\
\hline 200 & 20.11 & 20.44 & 21.33 & 23.55 & 21.36 \\
\hline 400 & 21.22 & 23.22 & 22.78 & 24.89 & 23.03 \\
\hline Mean (M) & 18.97 & 19.83 & 20.31 & 22.00 & \\
\hline L.S.D. at $5 \%$ & \multicolumn{2}{|c|}{ For $(C)=0.38$} & For $(M)=0.37$ & \multicolumn{2}{|c|}{ For $(C \times M)=0.74$} \\
\hline \multicolumn{6}{|c|}{2019 season } \\
\hline Control & 17.00 & 19.11 & 20.11 & 20.78 & 19.25 \\
\hline 100 & 18.00 & 18.78 & 22.67 & 25.33 & 21.19 \\
\hline 200 & 19.22 & 21.89 & 23.22 & 26.11 & 22.61 \\
\hline 400 & 20.22 & 22.45 & 23.78 & 26.44 & 23.22 \\
\hline Mean (M) & 18.61 & 20.56 & 22.44 & 24.67 & \\
\hline L.S.D. at $5 \%$ & \multicolumn{2}{|c|}{ For $(C)=0.41$} & For $(M)=0.45$ & \multicolumn{2}{|c|}{ For $(\mathrm{C} \times \mathrm{M})=0.88$} \\
\hline
\end{tabular}


$400 \mathrm{ppm}$ of chitosan and the application of micronutrients at $200 \mathrm{ppm}$ compared to the other ones under study in the $1^{\text {st }}$ and $2^{\text {nd }}$ seasons. The positive influences of these treatments (chitosan, micronutrients and their interactions) may be due to the important physiological role of chitosan in marjoram plants (El-Khateeb et al., 2017), also, iron and zinc are found in the most reactions and are fundamental for cellular processes and catalytic enzyme activities and in proteins and enzymes for structural tissues (Hall and Williams, 2003) that lead to taller, more branches and heaviest roots per lavender plant.

\section{Herb dry yield components:}

Data listed in Table (5) reveal that the concentration of chitosan at $400 \mathrm{ppm}$ recorded the highest values of total herb yield/plant (g) and total dry herb yield/feddan (kg) compared to non-applied plants (control) during the two consecutive seasons. Moreover, the abovementioned yield components showed gradual significant increases with increasing chitosan concentrations from 100 to $400 \mathrm{ppm}$ in both seasons. El-Gamal and Ahmed (2016) on coriander has been obtained similar results. In addition, Al-Tawaha et al. (2020) indicate that chitosan may be useful in the cultivation of barley, due to its positive and at the same time significant influence on growth and yielding of this plant. However, the highest number of grains yield, grains/spike and number of spikes were noticed by the foliar treatment of $10 \mathrm{~g} / \mathrm{l}$ chitosan at the tillering stage. These influences were observed with significant increase in lavender yield components under study in both seasons.

Data given in Table 5 demonstrate that, foliar spraying of micronutrients $(\mathrm{Fe}+\mathrm{Zn})$ significantly increased lavender herb yield per plant and per feddan compared with control in both seasons. The maximum mean values of total herb yield/plant and total dry herb yield /feddan under study were recorded with applying 200 ppm of both $\mathrm{Fe}$ and $\mathrm{Zn}$ in the two tested seasons. These results are in accordance with those found by
Salamatbakhsh et al. (2012) on castor bean, Yadegari (2015) on borago, thyme and marigold and Abd-Elkader (2016) on garlic.

Lavender herb yield/plant (g) and /feddan ( $\mathrm{kg})$ were significantly affected by chitosan concentration and spraying with micronutrient. In most cases, the interaction between different chitosan and micronutrient concentrations gave higher yield components values compared with control treatment. The highest values in this regard were obtained with the treatment of 400 ppm chitosan + 200 ppm micronutrients (Table, 5). Generally, as mentioned above, both micronutrients levels and chitosan concentrations (each alone) increased herb dry yield of lavender plant, in turn; they together might maximize their effects leading to more yielding for plant and feddan. However, the application of $\mathrm{Zn}$ and/or chitosan led to increases in shoot fresh mass of tomato plants, about $31 \%$, over control (Salimi et al., 2019).

Volatile oil production, chlorophyll and total carbohydrates:

Data recorded in Tables 6 and 7 suggest that, all chitosan concentration treatments increased volatile oil percentage and volatile oil yield per plant (ml) as well as total chlorophyll content (SPAD) and total carbohydrates percentage compared with control. Moreover, lavender volatile oil production and chemical constituents were gradually increased with increasing chitosan concentration. Since, the maximum increase in this respect was obtained from the treatment of high concentration of chitosan (400 ppm) compared with the other ones under study. These results agreed with those stated by Malekpoor et al. (2016) on basil, El-Khateeb et al. (2017) on marjoram, Byczyńska (2018) on pineapple lily and Abdul-Qader and Rabie (2019) on stevia plants.

Tables (6 and 7) indicate that, increasing micronutrients concentration gradually increased volatile oil production as well as total chlorophyll and total carbohydrates 
Table 5. Influence of chitosan (C) and micronutrients concentrations (M) as well as their interaction $(\mathrm{C} \times \mathrm{M})$ treatments on total dry herb/plant $(\mathrm{g})$ and /feddan (kg) of lavender plant during the two seasons of 2018 and 2019.

\begin{tabular}{|c|c|c|c|c|c|}
\hline \multirow{2}{*}{$\begin{array}{c}\text { Chitosan concentration } \\
\text { (ppm) }\end{array}$} & \multicolumn{4}{|c|}{ Micronutrients concentration (ppm) } & \multirow{2}{*}{ Mean (C) } \\
\hline & Control & 50 & 100 & 200 & \\
\hline \multicolumn{6}{|c|}{ Total dry herb/plant (g) } \\
\hline \multicolumn{6}{|c|}{2018 season } \\
\hline Control & 45.53 & 46.00 & 46.69 & 48.03 & 46.52 \\
\hline 100 & 45.79 & 47.50 & 48.06 & 50.02 & 47.84 \\
\hline 200 & 47.20 & 50.37 & 53.63 & 56.35 & 51.89 \\
\hline 400 & 49.92 & 50.77 & 56.00 & 57.98 & 53.67 \\
\hline Mean (M) & 47.07 & 48.66 & 51.09 & 53.09 & \\
\hline L.S.D. at 5\% & \multicolumn{2}{|c|}{ For $(C)=0.45$} & For $(M)=0.57$ & \multicolumn{2}{|c|}{ For $(\mathrm{C} \times \mathrm{M})=1.08$} \\
\hline \multicolumn{6}{|c|}{2019 season } \\
\hline Control & 42.53 & 45.31 & 48.41 & 50.03 & 46.57 \\
\hline 100 & 44.68 & 48.94 & 50.27 & 51.96 & 48.96 \\
\hline 200 & 46.16 & 50.97 & 51.97 & 56.09 & 51.30 \\
\hline 400 & 47.27 & 52.71 & 57.28 & 58.78 & 54.01 \\
\hline Mean (M) & 45.16 & 49.48 & 51.98 & 54.22 & \\
\hline L.S.D. at 5\% & \multicolumn{2}{|c|}{ For $(C)=0.74$} & M) $=0.51$ & \multicolumn{2}{|c|}{ For $(\mathrm{C} \times \mathrm{M})=1.14$} \\
\hline
\end{tabular}

Total dry herb/feddan (kg)

2018 season

$\begin{array}{cccccc}\text { Control } & 793.70 & 805.00 & 817.10 & 840.50 & 814.07 \\ \mathbf{1 0 0} & 801.30 & 831.20 & 841.00 & 875.30 & 837.19 \\ \mathbf{2 0 0} & 826.00 & 881.50 & 938.50 & 986.10 & 908.00 \\ \mathbf{4 0 0} & 873.70 & 888.50 & 980.00 & 1014.70 & 939.23 \\ \text { Mean (M) } & 823.65 & 851.55 & 894.13 & 939.23 & \end{array}$

\begin{tabular}{crrrrr} 
L.S.D. at 5\% & \multicolumn{2}{c}{ For $(\mathrm{C})=7.84$} & \multicolumn{2}{c}{ For $(\mathrm{M})=9.90$} & \multicolumn{2}{c}{ For $(\mathrm{C} \times \mathrm{M})=8.82$} \\
& \multicolumn{2}{c}{ 2019 season } \\
Control & 744.20 & 793.00 & 847.20 & 875.60 & 815.00 \\
$\mathbf{1 0 0}$ & 782.00 & 856.50 & 879.80 & 909.20 & 856.88 \\
$\mathbf{2 0 0}$ & 807.80 & 892.00 & 909.40 & 981.60 & 897.72 \\
$\mathbf{4 0 0}$ & 827.30 & 922.40 & 1002.50 & 1028.60 & 945.18 \\
Mean (M) & 790.32 & 865.97 & 909.72 & 948.76 &
\end{tabular}

L.S.D. at $5 \%$

For $(\mathrm{C})=12.91$

For $(\mathrm{M})=8.88$

For $(\mathrm{C} \times \mathrm{M})=20.02$ 
Table 6. Influence of chitosan (C) and micronutrients concentrations (M) as well as their interaction $(C \times M)$ treatments on volatile oil percentage and volatile oil yield/plant (ml) of lavender plant during the two seasons of 2018 and 2019.

\begin{tabular}{|c|c|c|c|c|c|}
\hline \multirow{2}{*}{$\begin{array}{c}\text { Chitosan concentration } \\
(\mathrm{ppm})\end{array}$} & \multicolumn{4}{|c|}{ Micronutrients concentration (ppm) } & \multirow{2}{*}{ Mean $(C)$} \\
\hline & Control & 50 & 100 & 200 & \\
\hline \multicolumn{6}{|c|}{ Volatile oil (\%) } \\
\hline \multicolumn{6}{|c|}{2018 season } \\
\hline Control & 0.592 & 0.602 & 0.628 & 0.634 & 0.614 \\
\hline 100 & 0.602 & 0.627 & 0.641 & 0.657 & 0.632 \\
\hline 200 & 0.622 & 0.634 & 0.662 & 0.680 & 0.649 \\
\hline 400 & 0.634 & 0.648 & 0.672 & 0.688 & 0.661 \\
\hline Mean (M) & 0.612 & 0.628 & 0.651 & 0.665 & \\
\hline L.S.D. at $5 \%$ & \multicolumn{2}{|c|}{ For $(C)=0.004$} & 1) $=0.003$ & \multicolumn{2}{|c|}{ For $(C \times M)=0.007$} \\
\hline \multicolumn{6}{|c|}{2019 season } \\
\hline Control & 0.536 & 0.573 & 0.588 & 0.595 & 0.573 \\
\hline 100 & 0.553 & 0.590 & 0.605 & 0.624 & 0.593 \\
\hline 200 & 0.580 & 0.593 & 0.619 & 0.636 & 0.607 \\
\hline 400 & 0.586 & 0.601 & 0.632 & 0.651 & 0.618 \\
\hline Mean (M) & 0.564 & 0.589 & 0.611 & 0.627 & \\
\hline L.S.D. at $5 \%$ & \multicolumn{2}{|c|}{ For $(C)=0.005$} & 1) $=0.007$ & \multicolumn{2}{|c|}{ For $(\mathrm{C} \times \mathrm{M})=0.013$} \\
\hline
\end{tabular}

Volatile oil yield/plant $(\mathrm{ml})$

2018 season

$\begin{array}{cccccc}\text { Control } & 0.268 & 0.277 & 0.293 & 0.305 & 0.286 \\ \mathbf{1 0 0} & 0.276 & 0.298 & 0.308 & 0.328 & 0.303 \\ \mathbf{2 0 0} & 0.293 & 0.319 & 0.355 & 0.383 & 0.338 \\ \mathbf{4 0 0} & 0.316 & 0.329 & 0.76 & 0.399 & 0.355 \\ \text { Mean (M) } & 0.288 & 0.306 & 0.333 & 0.354 & \end{array}$

L.S.D. at 5\% $\quad$ For $(C)=0.005$

For $(\mathrm{M})=0.004$

For $(\mathrm{C} \times \mathrm{M})=0.008$

2019 season

$\begin{array}{cccccc}\text { Control } & 0.228 & 0.260 & 0.285 & 0.298 & 0.267 \\ \mathbf{1 0 0} & 0.247 & 0.289 & 0.305 & 0.324 & 0.291 \\ \mathbf{2 0 0} & 0.268 & 0.303 & 0.322 & 0.357 & 0.312 \\ \mathbf{4 0 0} & 0.277 & 0.317 & 0.362 & 0.382 & 0.335 \\ \text { Mean (M) } & 0.255 & 0.292 & 0.318 & 0.340 & \end{array}$

L.S.D. at $5 \%$

For $(C)=0.006$

For $(M)=0.004$

For $(\mathrm{C} \times \mathrm{M})=0.009$ 
Table 7. Influence of chitosan (C) and micronutrients concentrations (M) as well as their interaction $(\mathrm{C} \times \mathrm{M})$ treatments on total chlorophyll content (SPAD) and total carbohydrates percentage of lavender plant during the two seasons of 2018 and 2019.

\begin{tabular}{|c|c|c|c|c|c|}
\hline \multirow{2}{*}{$\begin{array}{c}\text { Chitosan concentration } \\
\text { (ppm) }\end{array}$} & \multicolumn{4}{|c|}{ Micronutrients concentration (ppm) } & \multirow{2}{*}{$\operatorname{Mean}(\mathrm{C})$} \\
\hline & Control & 50 & 100 & 200 & \\
\hline \multicolumn{6}{|c|}{ Total chlorophyll content (SPAD) } \\
\hline \multicolumn{6}{|c|}{2018 season } \\
\hline Control & 46.11 & 46.44 & 47.11 & 47.89 & 46.89 \\
\hline 100 & 46.22 & 47.11 & 48.00 & 48.22 & 47.39 \\
\hline 200 & 47.11 & 48.66 & 50.55 & 52.78 & 49.78 \\
\hline 400 & 50.22 & 52.11 & 53.67 & 54.89 & 52.72 \\
\hline Mean (M) & 47.42 & 48.58 & 49.83 & 50.94 & \\
\hline L.S.D. at 5\% & \multicolumn{2}{|c|}{ For $(C)=0.51$} & \multicolumn{2}{|c|}{ For $(M)=0.33$} & For $(\mathrm{C} \times \mathrm{M})=0.77$ \\
\hline \multicolumn{6}{|c|}{2019 season } \\
\hline Control & 45.11 & 45.56 & 46.44 & 48.33 & 46.36 \\
\hline 100 & 45.78 & 46.89 & 48.11 & 48.22 & 47.25 \\
\hline 200 & 46.89 & 47.67 & 49.33 & 50.00 & 48.47 \\
\hline 400 & 49.44 & 51.89 & 53.11 & 53.78 & 52.06 \\
\hline Mean (M) & 46.81 & 48.00 & 49.25 & 50.08 & \\
\hline L.S.D. at $5 \%$ & \multicolumn{2}{|c|}{ For $(C)=0.40$} & $(M)=0.75$ & \multicolumn{2}{|c|}{ For $(\mathrm{C} \times \mathrm{M})=1.35$} \\
\hline
\end{tabular}

Total carbohydrates percentage

2018 season

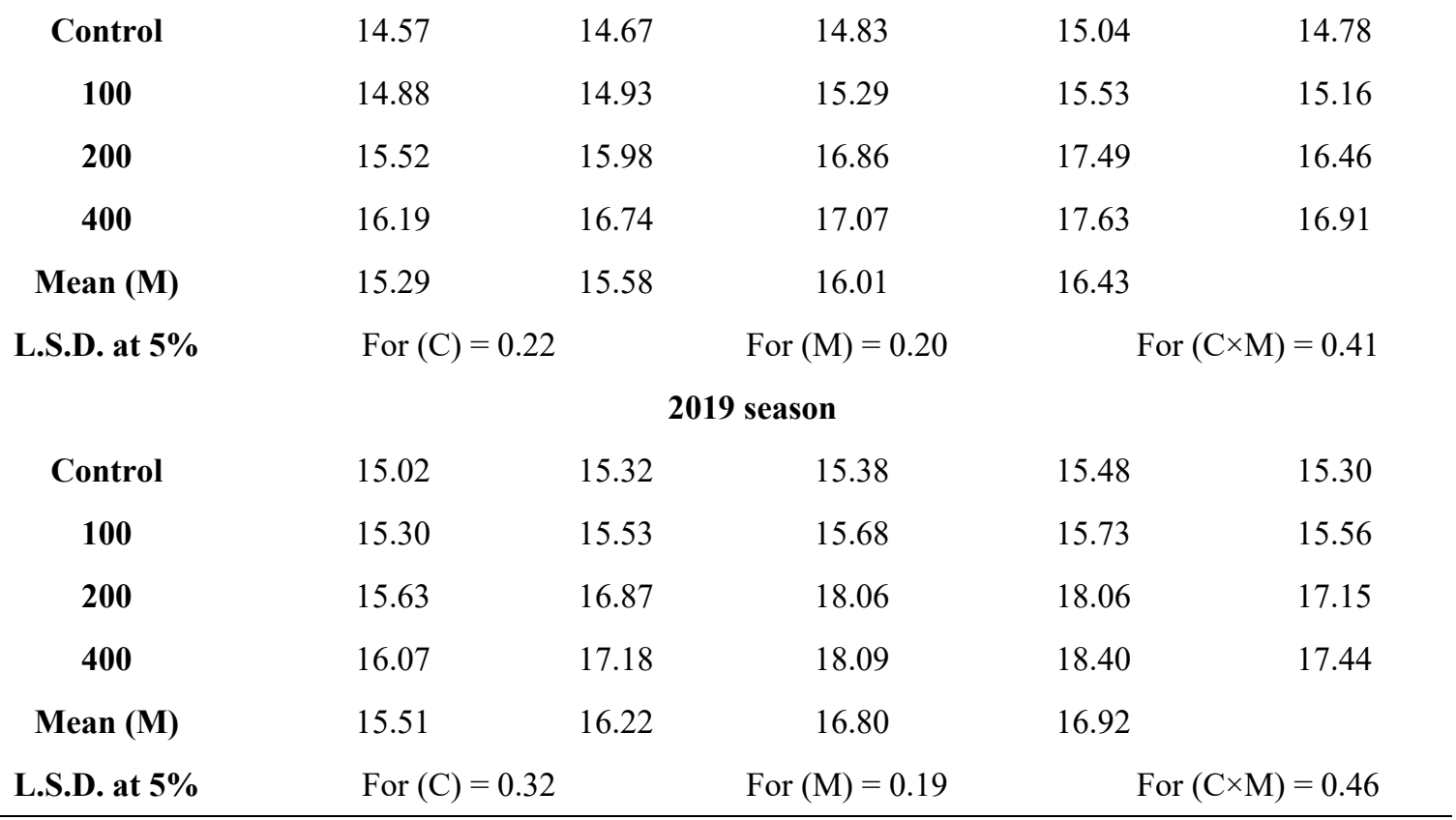


percentage of lavender plant in both seasons. Generally, lavender volatile oil production and chemical constituents were significantly increased with application of the three concentrations of micronutrient treatments $\left(\mathrm{FeSO}_{4}+\mathrm{ZnSO}_{4}\right.$ at 50, 100 and $200 \mathrm{ppm}$, respectively) compared to untreated plants (control). Moreover, $\mathrm{FeSO}_{4}+\mathrm{ZnSO}_{4}$ at 200 ppm recorded higher increase in this connection compared with the other two ones under study. The improved vegetative growth of lavender plant and yield attributing parameters due to iron and zinc application has also direct relation in improvement of growth development and increase in volatile oil production of dill (Mirshekari and Siyami, 2014). Similar results were stated by Nasiri and Najafi (2015) on chamomile and Amini et al. (2018) on hyssop plants.

Results under discussion in Table 9 indicate that, under each treatment of chitosan concentration volatile oil production as well as total chlorophyll and total carbohydrates percentage of lavender were increased with increasing micronutrients $(\mathrm{Fe}+\mathrm{Zn})$ concentration. Generally, volatile oil production and chemical constituents were significantly increased with all interaction treatments between chitosan and micronutrients concentrations compared with control in both seasons. Similarly, under each micronutrient concentration treatment these parameters were increased by increasing chitosan concentration. In the same time, the interaction treatment between the highest concentration of chitosan and high rate of micronutrients was superior in increasing volatile oil production and pigments compared to the other ones under study in the first and second seasons. However, it is now clear that using of high concentration of micronutrients interacted with high concentration of chitosan gave the highest values of volatile oil production and chemical constituents of lavender. This might be attributed to three factors. First, the role of chitosan at this rate in promoting photosynthesis and assimilates accumulation and consequently more increase in branch number and weight which reflected in volatile oil production. Second, micronutrients may improve ability of the lavender plant to absorb nutrients, photosynthesis and better sink source relationship as these play vital role in various biochemical processes. Third, the low intracompetition between lavender plants on available micronutrients and polysaccharides.

\section{CONCLUSION}

From the above mentioned results, it is preferable to spray Lavandula officinalis, plants with chitosan at $400 \mathrm{ppm}$ five times a season with high micronutrients concentration $\left(\mathrm{FeSO}_{4}+\mathrm{ZnSO}_{4}\right.$ each at 200 $\mathrm{ppm})$ to enhance the growth, yield components as well as volatile oil production and total chlorophyll content of lavender plant under Sharkia Governorate conditions.

\section{REFERENCES}

Abd-Elkader, D.Y. (2016). Effect of foliar spraying with micronutrients and salicylic acid on growth, yield and quality of garlic plants. Alex. J. Agric. Sci., 61(6):649-658.

Abdul-Qader, Z.M. and Rabie, K.M. (2019). The effect of planting date, adding of mycorrhiza, bio-stimulators, and interactions among them in the accumulation of some active compounds in the different parts of Stevia rebaudiana Bertoni. plant cultivated in Iraq. Research Journal of Pharmaceutical, Biological and Chemical Sciences, 10(1):295-318.

Al-Tawaha, A.M.; Jahan, N.; Odat, N.; AlRamamneh, E.; Al-Tawaha, A.; AbuZaitoon, Y.M.; Fandi, K.; Alhawatema, M.; Wedyan, M.; Shariati, M.A.; Qaisi, A.M.; Tawaha, K.I.; Turk, M. and Khanum, S. (2020). Growth, yield and biochemical responses in barley to DAP and chitosan application under water stress. Journal of Ecological Engineering, 21(6):86-93. 
Amini, M.; Yousefzadeh, S. and SadatAsilan, K. (2018). A study on variations of essential oil yield and composition of Hyssopus officinalis L. affected by foliar application of zinc, iron and manganese. Iranian Journal of Medicinal and Aromatic Plants, 34(1):131-143.

Analytical Software (2008). Statistix Version 9, Analytical Software, Tallahassee, Florida, USA.

Byczyńska, A. (2018). Chitosan improves growth and bulb yield of pineapple lily (Eucomis bicolor Baker) an ornamental and medicinal plant. World Scientific News, 110(9):159-171.

Chapman, H. and Pratt, P. (1978). Methods of Analysis for Soils, Plants and Waters. Div. Agric., Sci. Univ. Calif. USA, pp. 16-38.

Dubois, M.; Gilles, K.A.; Robers, J. H. and Smith, F. (1956). Colorimetric methods for determination of sugar and related substances. Anal. Chem., 28: 350-356.

El-Gamal, S.M.A. and Ahmed, H.M.I. (2016). Optimization coriander production for fruit and essential oil, B: Yield improvement by chitosan and salicylic acid foliar application. J. Plant Production, Mansoura Univ., 7(12):14811488.

El-Khateeb, M.A.; El-Attar, A.B. and Nour, R.M. (2017). Application of plant biostimulants to improve the biological responses and essential oil production of marjoram (Majorana hortensis, Moench) plants. Middle East Journal of Agriculture Research, 6(4):928-941.

Gomez, K. A. and Gomez, A. A. (1984). Statistical Procedures for Agricultural Research. $2^{\text {nd }}$ Ed., John Wiley \& Sons Inc., New York, 680 p.

Guenther, E. (1961). The Essential Oil. D. Van Nostrand Comp., New York, 1: 230236.
Hall, J.L. and Williams, L.E. (2003). Transition metal transporters in plants. J. Exp. Bot., 54(393):2601-2613.

Hassanpouraghdam, M.B.; Hajisamadi, B. and Khalighi, A. (2011). Gibberellic acid foliar application influences growth, volatile oil and some physiological characteristics of lavender (Lavandula officinalis Chaix.). Romanian Biotechnological Letters, 16(4):63226327.

Iriti, M.; Picchi, V.; Rossoni, M.; Gomarasca, S.; Ludwig, N.; Gargano, M. and Faoro, F. (2009). Chitosan antitranspirant activity is due to abscisic acid-dependent stomatal closure. Environmental and Experimental Botany, 66: 493-500.

Kaya, M.; Atak, M.; Mahmood, K.K.; Çiftçi, C.Y. and Özcan, S. (2005). Effect of presowing seed treatment with zinc and foliar spray of humic acids on yield of common bean (Phaseolus vulgaris L.). Int. J. Agri. Biol., 6(7):875-878.

Lawless, J. (1995). The Illustrated Encyclopedia of Essential Oils: The Complete Guide to The Use of Oils in Aromatherapy and Herbalism. Element Books Ltd., UK, 256 p.

Malekpoor, F.; Pirbalouti, A.G. and Salami, A. (2016). Effect of foliar application of chitosan on morphological and physiological characteristics of basil under reduced irrigation. Res. on Crops, 17(2):354-359.

Malerba, M. and Cerana, R. (2018). Recent advances of chitosan applications in plants. Polymers, 118(10):1-10.

Maluin F.N. and Hussein, M.Z. (2020). Chitosan-Based agronanochemicals as a sustainable alternative in crop protection. Molecules, 1611:1-22.

Markwell, J.; Osterman, J.C. and Mitchell, J.L. (1995). Calibration of the Minolta SPAD-502 leaf chlorophyll meter. Photosynthesis Res., 46:467-472. 
Marschner, H. (1995). Mineral Nutrition of Higher Plants. $2^{\text {nd }}$ Ed. New York: Acad., $889 \mathrm{p}$.

Mehrab, Y. (2017). Effects of Zn, Fe, Mn and $\mathrm{Cu}$ foliar application on essential oils and morpho-physiological traits of lemon balm (Melissa officinalis L.). Journal of Essential Oil Bearing Plants, 20(2):485495.

Mehregan, M.; Mehrafarin, A.; Labbafi, M.R. and Naghdi Badi, H. (2017). Effect of different concentrations of chitosan biostimulant on biochemical and morphophysiological traits of stevia plant (Stevia rebaudiana Bertoni). J. Med. Plants, 16:169-181.

Mirshekari, B. and Siyami, R. (2014). Positive response of essential oil percentage and its yield to seed pretreatment with some of major microelements. Case study: Anethum graveolens as a medicinal plant. Indian J. of Fundamental and App. Life Sci., 4(2):453-461.

Nasiri, Y. and Najafi, N. (2015). Effects of soil and foliar applications of iron and zinc on flowering and essential oil of chamomile at greenhouse conditions. Acta Agriculturae Slovenica, 105(1):3341.

Pichyangkura, R. and Chadchawan, S. (2015). Biostimulant activity of chitosan in horticulture. Scientia Horticulture, 196:49-65.

Pirbalouti, A.G.; Malekpoor, F.; Salimi, A. and Golparvar, A. (2017). Exogenous application of chitosan on biochemical and physiological characteristics, phenolic content and antioxidant activity of two species of basil (Ocimum ciliatum and Ocimum basilicum) under reduced irrigation. Scientia Horticulture, 217:11422.

Salamatbakhsh, M.R.; Tobe, A. and Taherifard, E. (2012). Effects of foliar application of micronutrients on yield and yield components of castor bean
(Ricinus communis L.) varieties. European Journal of Experimental Biology, 2(4):975-979.

Salimi, A.; Ardebili, Z.O. and Salehibakhsh, M. (2019). Potential benefits of foliar application of chitosan and zinc in tomato. Iranian Journal of Plant Physiology, 9(2): 2703-2708.

Schnaubelt, K. (1998). Advanced Aromatherapy; the Science of Essential Oil Therapy, Inner Traditions Ltd., Germany, $144 \mathrm{p}$.

Soliman, A.M.I.; Awad, A.E.; Gendy, A.S. and Abdelkader, M.A. (2018). Influence of foliar application of $\mathrm{Fe}, \mathrm{Zn}$, Mo and lithovit on growth and productivity of stevia plant (Stevia rebaudiana, Bert.). Zagazig J. Agric. Res., 45(6):1633-1644.

Worwood, V. (1991). The Complete Book of Essential oils and Aromatherapy, New World Library, $712 \mathrm{p}$.

Yadegari, M. (2015). Foliar application of micronutrients on essential oils of borago, thyme and marigold. Journal of Soil Science and Plant Nutrition, 15(4):120.

Yusufoglu, A.; Celik, H. and Kirbaslar, G. (2004). Utilization of Lavandula angustifolia Miller extracts as natural repellents, pharmaceutical and industrial auxiliaries. J. Serb. Chem. Soc., 96:1-7.

Zehtab-Salmasi, S.; Heidari, F. and Alyari, H. (2008). Effects of microelements and plant density on biomass and essential oil production of peppermint (Mentha piperita L.). Pl. Sci. Res., 1: 24-26.

Ziedan, E.H. and Eisa, E.A. (2016). The use of some micronutrients and plant extracts of resistance to powdery mildew and nutrition dill plants in the Gharbiyah Governorate. J. Plant Prot. and Path., Mansoura Univ., 7(9):579-586. 


\title{
تأثير تركيزات الثيتوزان والعناصر الصغرى (الحديد + الزتلك) على نمو والمكونات المحصولية و والزيت العطري النبات اللافندر الزئر
}

\author{
أسماء أحمد فهمي و ولبد صبري نصبير \\ قسم البساتين ـ كلية الزراعة ـ جامعة الزفازيق ، مصر فئر
}

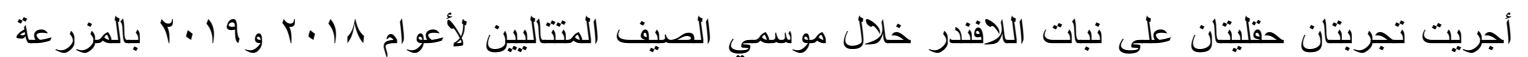

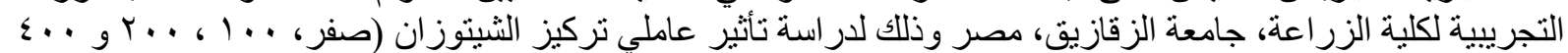

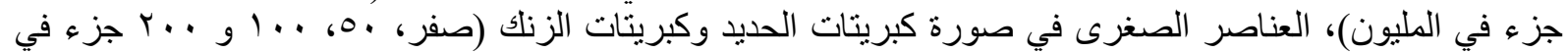

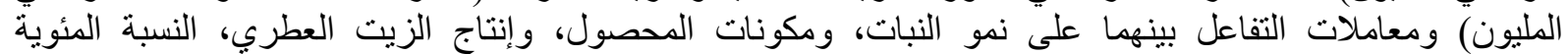

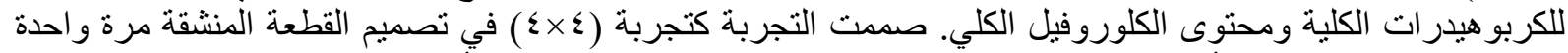

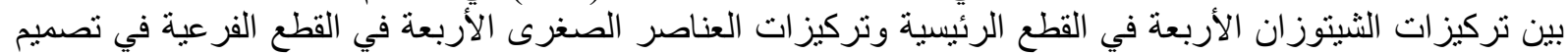

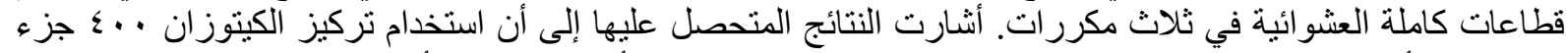

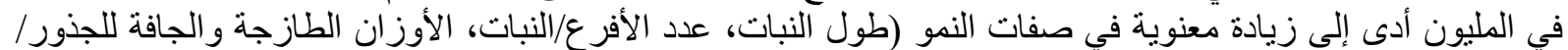

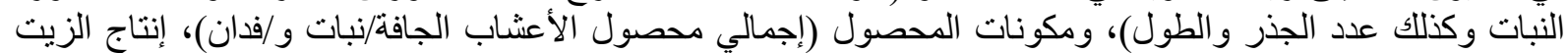

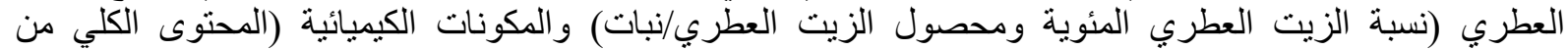

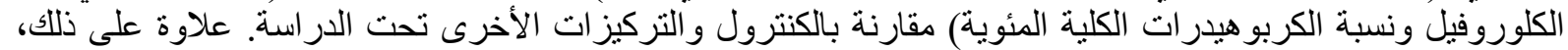

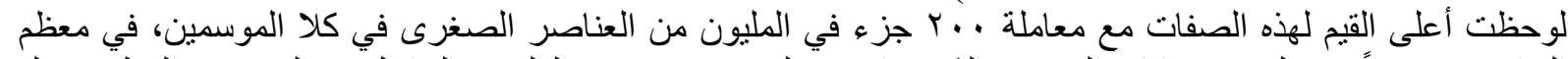

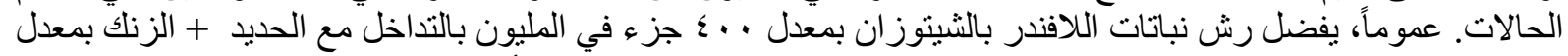

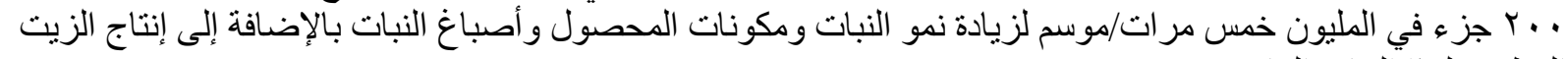
العطري لهذا النبات الهام. 